Missio Ecclesiae, 7(2), Oktober 2018, 259-286

\title{
PEMULIHAN ALKITABIAH TERHADAP KONSEP DIRI IRASIONAL KAUM MUDA
}

\author{
Triani Devita Sinaga
}

\section{PENDAHULUAN}

Setiap manusia memiliki konsep diri. Konsep diri bukan merupakan faktor bawaan atau herediter. Konsep diri merupakan faktor bentukan dari pengalaman individu selama proses pembentukan dan perkembangan dirinya dari lahir hingga dewasa. Burn R. B menyatakan bahwa "konsep diri berkembang terus sepanjang hidup manusia, namun pada tahap tertentu perkembangan konsep diri mulai berjalan dalam tempo yang lebih lambat." 1

Faktanya dalam perjalanan kehidupan manusia, konsep diri terbentuk melalui proses belajar sejak masa pertumbuhan dari kecil hingga dewasa. Proses inilah yang memberikan pengaruh signifikan terhadap pembentukan konsep diri. Sejauh mana kontribusi pembentukan itu mempengaruhi maka seperti itulah tertanam dalam diri seseorang menerima konsep dirinya (siapa diri yang sebenarnya 'kepribadian' dan pola kehidupan kerohanian yang stabil yang akan dijalaninya); bisa konsep diri rasional (berpikir positif terhadap keberadaan dan siapa dirinya apa adanya) atau menjadi orang yang memiliki konsep diri irasional (pikiran yang negative yang sulit menerima keberadaan dan siapa dirinya 'tidak bisa menerima kenyataan' meskipun sebenarnya dirinya tidak seperti penilainya atau penilaian orang lain).

Problematikanya, permasalahan rumit yang dialami dan yang dihadapi manusia, seringkali dan bahkan hampir semuanya, sebenarnya berasal dari dalam diri sendiri. Alasannya karena "Setiap manusia mendambakan perasaan bahwa hidupnya bermakna, bahwa dirinya seorang yang berharga, dan perlu diperlakukan secara bermartabat. Pengakuan, penghargaan, dan pujian dari orang lain akan membuat siapa saja melambung dalam kebahagiaan - setiap orang mendambakan hal ini: sebaliknya penghinaan, pengabaian, dan pelecehan akan sangat terasa menyakitkan - setiap orang sangat membenci perlakuan yang menganggap diri mereka hina dan tidak berharga". ${ }^{2}$

Namun bukan berarti dalam proses pemulihan Alkitabiah meniadakan psikologi. Seorang konselor perlu memliki pengetahuan tentang psikologi supaya tidak salah dalam memberikan konseling. Pemulihan menurut Alkitab menjadi tanggung jawab Gereja, Orang Tua, Gembala Jemaat, dan Jemaat. Kaum Muda yang mengalami konsep diri irasional perlu dipulihkan. oleh sebab itu penulis mengangkat judul Pemulihan Alkitabiah terhadap Konsep Diri 'Irasional' Kaum Muda.

\footnotetext{
${ }^{1}$ Dalam tulisan Burn, R.B, (1997)Ttps: tulisantantim.wordpress.com. diakses 15 Maret 2017

2 R.C.Sproul, Mendambakan Makna Diri "The Hunger For Significance, (Surabaya:Momentum, 2005), 1
} 


\section{Tuhan Adalah Pencipta Manusia}

Allah menciptakan manusia, berarti Allah adalah Pencipta dan manusia adalah ciptaan. Konsep ini haruslah dimiliki oleh setiap individu dengan benar dan tepat supaya dalam pengaktualisasi dirinya tidak salah. Manusia ada dalam dunia bukan karena dirinya sendiri dan bukan karena kehendak manusia. Manusia ada dan berada dalam dunia karena Allah (band. Kejadian 1:26, 2:7). Allah menciptakan manusia langsung. Manusia bukanlah keturunan Allah, bukan mengalir keluar daripada Allah, tetapi diciptakan Allah. ${ }^{3}$

Penilaian diri manusia tentang konsep dirinya haruslah didasarkan pada tujuan Allah menciptakan manusia menurut Alkitab. Oleh karena menurut konsep 'pandangan umum' yang ada sangatlah bertentangan dengan Alkitab. Ketika manusia memikirkan diri maka akan muncul dua ekstrim yaitu pertama melihat diri begitu hina dan tidak berarti, kedua melihat diri begitu hebat seperti Allah sendiri. ${ }^{4}$ John Calvin mengajarkan bahwa "mengenal diri terkait erat dengan mengenal Allah. Mengenal Allah bukan yang abstrak melainkan dalam konteks diri manusia yang diciptakan Allah". 5

Tujuan Allah menciptakan manusia adalah untuk mengekspresikan kemulian-Nya (Amsal 16:4), karena itulah melalui ciptaan manusia, Allah menghendaki supaya manusia melakukan kehendak dan rancangan-Nya yang sempurna.

\section{Manusia Menurut Gambar Dan Rupa Allah}

Allah menghendaki manusia diciptakan berbeda dengan ciptaan lainnya. Keistimewaan manusia dari ciptaan Allah yang lainnya ialah diciptakan menurut gambar dan rupa Allah. R. Soedarmo menyatakan bahwa "manusia itu berbeda sekali dengan makhluk-makhluk lainnya. Tuhan Allah menjadikan manusia memang berbeda dengan menjadikan makhluk-makhluk lainnya". ${ }^{6}$ Dari Kejadian 1:26-27 dapat diketahui bagaimana karya Allah menjadikan atau menciptakan manusia yang berbeda sekali dengan cara ciptaan Tuhan lainnnya. Manusia pertama diciptakan Tuhan dalam jangka waktu yang singkat dan langsung sebagai manusia dewasa yang sempurna. Manusia pertama tidak melalui proses kelahiran; setelah itu kehadiran manusia selanjutnya ada karena proses kelahiran (semua manusia adalah keturunan Adam dan Hawa).

Kata 'gambar' dan 'rupa' tidak mempunyai perbedaan yang hakiki, kedua kata ini menunjuk kepada hal yang sama. Dalam bahasa Ibrani gambar 'tselem'; bahasa Inggris 'image'; bahasa Yunani 'morphe' yang berarti suatu peta yang ada bentuk. Sedangkan arti kata 'rupa' adalah 'demuth (bahasa Ibrani); likeness (bahasa Inggris); 'skema' (Yunani) yang berarti suatu bentuk yang bersesuai dengan bentuk pertamanya (peta). Ini artinya bahwa manusia diciptakan berdasarkan, menurut 'gambar' yang sudah ada yaitu Allah. Pengertiannya adalah bahwa melalui ciptaan apa yang semula merupakan bentuk awal yang ada pada Allah kemudian 'dicetakkan' pada manusia. Allah adalah yang

\footnotetext{
${ }^{3}$ Harun Hadiwijono, Iman Kristen, (Jakarta: BPK Gunung Mulia, 1997), 173

4 www.girl-andhika.org, diakses 20 Mei 2017, Konsep Diri dalam Spritualitas Alkitab VS

5 Ibid.

${ }^{6}$ R.Soedarmo, Ikhtisar Dogmatika, (Jakarta: BPK Gunung Mulia, 1996), 139.
} Spritualitas Postmodern. 
aslinya dan manusia adalah salinannya. ${ }^{7}$ Louis Berkhof mengatakan "Makna dari gambar dan rupa Allah" mencakup:

1. Gambar dan rupa Allah terkandung di dalamnya bahwa manusia memiliki apa yang yang disebut dengan kebenaran asali. Hal ini mencakup hal pengetahuan yang benar, kebenaran dan kesucian di dalam dirinya.

2. Gambar dan rupa Allah mengacu pada elemen-elemen yang menjadi natur konstitusional manusia seperti kekuatan intelektual, perasaan natural dan kebebasan moral.

3. Gambar dan rupa Allah mengacu pada kerohanian manusia. Manusia bukan saja terdiri dari tubuh jasmani akan tetapi juga memiliki kerohanian yang memungkinkan manusia berhubungan dengan Allah. ${ }^{8}$

Berdasarkan pemahaman tentang penciptaan manusia menurut gambar dan rupa Allah, manusia akan menempatkan diri secara benar sebagai makhluk yang diciptakan dan akan menghormati Penciptanya sebagai Pribadi yang berkuasa penuh di dalam hidupnya. Dan manusia sebagai ciptaan Allah ada untuk menggenapi rencana Allah untuk kemuliaan Allah.

\section{Manusia Hidup Dalam Ketentuan Allah}

Manusia dipilih dan diciptakan Allah bagi diri-Nya. Allah memilih manusia bahkan sebelum dunia dijadikan. Dia menginginkan manusia untuk hidup kudus dan tak bercacat dihadapan-Nya dengan kasih. Dengan demikian Allah menciptakan manusia untuk kemuliaan-Nya, yaitu memuliakan nama-Nya (Efesus 1:4, Yesaya 43:7). Oleh karena itu hal yang perlu dipahami yaitu:

Inilah tujuan Allah menciptakan manusia, yaitu bagi kemuliaan-Nya. Apapun yang kita lakukan, siapapun kita, manusia adalah ciptaan-Nya, milik-Nya yang ditujukan untuk hidup di dalam ketentuan-Nya bagi kemuliaan Allah sendiri. Meskipun demikian, Allah tidak menjadikan manusia sebagai budak, Dia menciptakan manusia dalam kasih dan Ia mengasihi manusia milik-Nya itu. Allah menginginkan manusia hidup suci seperti halnya Dia adalah Allah yang suci, supaya manusia dapat hidup bersama-sama dengan Dia, hidup dalam persekutuan yang penuh kasih dengan Dia yang adalah Kasih. ${ }^{9}$

Inilah ketentuan Allah bagi manusia, supaya manusia yang adalah milik Allah bisa menjalankan kehidupannya menurut aturan Allah. Dari awal manusia diciptakan Tuhan sudah memberikan ketentuan bagi manusia yaitu melaksanakan amanat kebudayaan dan ada peraturan yang tidak boleh dilanggar manusia supaya manusia hidup untuk kemulian Tuhan. Inilah tujuan Allah; Dia menciptakan manusia bagi kemuliaan-Nya, karena Dia adalah pencipta manusia, Dia berkuasa atas kita buatan dan milik-Nya (band Kolose 1:16, Yohanes 1:3).

\footnotetext{
${ }^{7}$ Louis Berkhof, Teologi Sistematika “Doktrin Manusia” Jilid 2, (Jakarta: Lembaga Reformed Injili Indonesia), 46.

${ }^{8}$ Ibid., 47-50.

${ }^{9}$ Pesan kasih dari surga.blogspot.com. Pesan Injil: Tujuan Allah Menciptakan Manusia-bag2, diakses 18 Mei 2018
} 


\section{Manusia Seperti Allah Tapi Bukan Allah}

Tuhan membuat manusia hampir sama seperti Allah (Mazmur 8:3-5). Firman Allah mengatakan bahwa manusia diciptakan hampir sama dengan Allah, namun dipertegas bahwa manusia bukanlah Allah, Allah Pencipta bukan ciptaan lain, bukan juga malaikat. Dengan demikian manusia harus menyadari posisi dirinya dengan tepat. Allah menempatkan manusia dalam suatu hubungan yang meninggikan manusia di atas ciptaan lainnya. Manusia diciptakan untuk memantulkan kemuliaan Allah. ${ }^{10}$

Laporan Kitab Kejadian tentang penciptaan mencatat bahwa waktu Allah menciptakan manusia, Ia mengambil sikap yang menunjukkan perhatian yang sangat pribadi dan mendalam terhadap manusia (Kej. 1:26; band 1:3,6). Dan cara pendekatan-Nya ialah melibatkan diri-Nya dalam hubungan yang lebih erat dengan manusia ciptaan-Nya itu dibandingkan dengan semua ciptaan lainnya, manusia dimampukan menanggapi ucapan Allah yang penuh kasih itu dengan kasih pribadi dan kepercayaan. Hanya dalam jawaban demikianlah manusia bisa menjadi 'apa sebenarnya dia". Allah menempatkan manusia dalam suatu hubungan yang meninggikan manusia di atas ciptaan lainnya. Manusia diciptakan untuk memantulkan kemuliaan Allah.

Allah tidak terlihat, tidak ada yang bisa melihat, namun Allah dapat dilihat dari manusia, karena manusia adalah ciptaan Allah yang serupa dengan Allah.Dengan demikian manusia diciptakan seperti Allah mengajarkan bahwa hidup manusia mempunyai tujuan. Ini menandakan manusia mempunyai makna hidup. Manusia seperti Allah berarti harus memperbaiki hidup untuk menyenangkan atau memuliakan Allah.

\section{Manusia Jatuh Dalam Dosa}

Hubungan Allah dan manusia pertama sebelum jatuh dalam dosa tidak mengalami kerusakan. Komunikasi antara Adam dan Allah terjaga harmonis, 'manusia meskipun telanjang tidak malu'. Namun fakta dalam Kejadian 3 selanjutnya menjelaskan bahwa gambaran keadaan dan keberadaan manusia mengalami kerusakan total karena dosa. R. Soedarmo mengatakan "Gambar Tuhan sekarang menjadi negatif, artinya menunjukkan yang tidak dikehendaki oleh Tuhan. Maka dari itu gambar Tuhan pada manusia bukannya hilang tetapi rusak dan terbalik sama sekali. Manusia tidak mau menjadi gambar Tuhan akan tetapi ingin menjadi ilah sendiri. ${ }^{12}$ Adapun pembahasannya adalah sebagai berikut:

\section{Akibat Dosa Merusak Keyakinan Akan Diri Sendiri}

Alkitab mengajarkan semua manusia pada hakekatnya mati dalam pelanggaranpelanggaran dosa sehingga sama sekali tidak dapat menyenangkan Allah (Roma 8:7-8, Ef. 2:1-2). Manusia pertama, Adam dan Hawa jatuh dalam dosa mengakibatkan

${ }^{10}$ J.D. Douglas, Ensiklopedi Alkitab Masa Kini 'Manusia', (Jakarta: Yayasan Komunikasi Bina Kasih/OMF, 1997), 25

${ }^{11}$ Ibid., 25

${ }^{12}$ R. Soedarmo, Ikhtisar..., 154 
perubahan yang sangat dratis dalam kehidupan mereka dan keturunannya (Mazmur 51:7). Sejak Adam jatuh ke dalam dosa, manusia itu berpaling dari kebenaran, semua bagian jiwa (nefesy atau psyche) juga telah dirasuki dosa. Manusia itu pada hakikatnya telah "total corruptian" (kerusakan total) yang berati tiada satupun dari segi watak manusia yang luput dari pengaruh dosa. dosa membelokkan arah kehidupan manusia, yang semula untuk memuliakan Allah menjadi memuliakan diri sendiri. Merusak hubungan baik antara Allah dan manusia, antara manusia dengan manusia dan juga manusia dengan dirinya sendiri. Manusia membenci Allah (Yoh. 12:23,24), hidup tanpa Allah (Luk. 15:21), tidak layak di sebut anak-anak Allah (Luk. 15:21), membenci sesamanya (Kej. 3:12), terpisah dari dasar keberadaannya dan dari diri sendiri. ${ }^{13}$

Manusia pertama memiliki keyakinan bahwa mereka sangat dikasihi dan bernilai serta aman dalam rancangan Allah. Relasi keterbukaan dan ketidakmaluan terjalin sangat harmonis dalam kebersamaan mereka di taman Eden. Perilaku dan pengaktualisasi diri ditempatkan dengan benar dalam menerima diri dan orang lain disekitarnya. Kemampuan untuk menilai ciptaan Tuhan lainnya menjadi kebanggaan dan hak istimewa yang mereka dapatkan.

Akibat dosa, keyakinan menjadi berubah; saat Allah bertanya kepada Adam, Adam menjawab Allah dengan bersembunyi karena menilai dirinya telanjang dan takut menghadapi Allah. Rasa malu dan ketakutan merajai diri mereka. Kemampuan untuk memahami diri sebagai ciptaan Tuhan menjadi rusak, sehingga manusia berusaha menutupi diri dan mencari solusi sendiri untuk menutupi keberadaannya. Keadaan dan keberadaan yang telah jatuh dalam dosa yang dilakukan oleh Adam dan Hawa, terus diikuti oleh keturunannya. ${ }^{14}$

\section{Penilaian Diri Terhadap Tuhan Dan Diri Sendiri Salah}

Tindakan manusia sebelum mengambil keputusan untuk memberontak terhadap Tuhan dalam kejadian pasal 3; salah satunya manusia dipengaruhi oleh lingkungan (iblis datang menyerupai ular dalam taman eden) untuk mempengaruhi pola pikir manusia tentang Allah dan diri manusia. Pengaruh yang dilakukan iblis yaitu memutarbalikan atau memalsukan kebenaran firman Tuhan, manusia kehilangan keyakinan akan kasih Allah membuat manusia mengambil keputusan untuk jatuh dalam dosa.

Manusia yang mulai meragukan dan tidak mempercayai Allah dalam kehidupannya, cenderung menilai Tuhan dengan salah; berakibat manusia juga

${ }^{13}$ E.P.Gintings, Pastoral Konseling; Membaca Manusia Sebagai Dokumen Hidup, (Yogyakarta: Andi, 2016), 49

14 Akar berbagai persoalan yang kita hadapi adalah hakikat kita sebagai manusia! Tidak ada penyebab lain kecuali hakikat manusiawi kita sendiri - karena pada hakekatnya, kita adalah manusia berdosa. Alkitab menyatakan bahwa kecenderungan untuk berbuat dosa, itulah yang menjerumuskan kita ke dalam berbagai persoalan. Kita memilih untuk melakukan hal-hal yang merusak diri, sekalipun sebenarnya kita mengetahui pilihan yang lebih baik. Ketika hati terluka kita menanggapinya dengan cara yang menyakitkan pula. Ketika mencoba memperbaiki keadaan sering kali justru memperparah keadaan. Jika kita menggunakan cara sendiri, hakikat dosa kita mendorong kita untuk berbuat dosa, berhasrat menyamai Allah, dan berusaha bertindak seperti Allah. John Baker, 8 Pilihan Hidup Bahagia, (Jakarta: BPK Gunung Mulia, 2009), 16 
mempersalahkan dirinya atau tidak bisa menerima dirinya seperti yang Tuhan sudah berikan.

John Baker menjelaskan bahwa akar persoalan manusia jatuh dalam dosa berakibat pada "Kecenderungan untuk berbuat dosa, hasrat untuk menyamai Allah, berusaha bertindak seperti Allah (mencoba mengendalikan citra diri, mencoba mengendalikan orang lain, memegang kendali atas persoalan sendiri, mencoba mengendalikan kepedihan kita)" ${ }^{15}$ Keberadaan dan kepribadian manusia yang belum terlepas dari dosa mendorong untuk berbuat dosa, berhasrat menyamai Allah, bertindak seperti Allah dan mempersalahkan Allah.

\section{Penaksiran Diri (Reflected Appraisal)}

Konsep diri terbentuk akibat pengalaman interaksi dengan orang lain yaitu dengan menemukan apa yang orang lain pikirkan tentang dirinya. Setelah itu penilaian dari orang lain, baru menilai diri sendiri (reflected appraisal).

Penilaian diri merupakan pandangan diri terhadap: Pertama, pengendalian keinginan dan dorongan-dorongan dalam diri. Bagaimana kita mengetahui dan mengendalikan dorongan, kebutuhan dan perasaan perasaan dalam diri kita. Kedua, suasana hati yang sedang kita hayati seperti bahagia, sedih atau cemas. Keadaan ini akan mempengaruhi konsep diri kita positif atau negatif. Ketiga, bayangan subyektif terhadap kondisi tubuh kita. Konsep diri yang positif akan dimiliki kalau merasa puas (menerima) keadaan fisik diri sendiri. Sebaliknya, kalau merasa tidak puas dan menilai buruk keadaan fisik sendiri maka konsep diri juga negatif atau akan jadi memiliki perasaan rendah diri. ${ }^{16}$

Beberapa contoh tokoh-tokoh Alkitab yang mengalami Penaksiran Diri (Reflected Appraisal), ialah: Kain dan Habel diasuh oleh Adam dan Hawa (Kejadian 4); meskipun tidak diceritakan bagaimana pola asuh yang diberikan dalam keluarga dan lingkungan, dapat diperhatikan ketika Kain dan Habel memberikan persembahan kepada Tuhan. Kain mengalami konsep diri irasional ketika persembahannya tidak diterima, Kain menilai dan memperhatikan dan membandingkan dirinya dengan adiknya Habel. Sehingga Kain merasa kecewa, marah, sakit hati. Akibat Kain tidak bisa menguasai diri, Kain berpikir dan mengambil keputusan serta bertindak membunuh Habel. Saul (1Sam. 9:16-21). Saul juga sebelum diurapi menjadi raja Israel, ia merasa minder dan merasa tidak memenuhi syarat. (1Sam. 9:21).

Kemampuan manusia untuk melakukan penaksiran diri terhadap proses pembentukan konsep diri yang sehat sesuai rancangan Tuhan dengan mengandalkan diri sendiri sulit untuk terbebas dari tabiat dosa. Manusia butuh pertolongan orang lain 'Konseling Kristen' yang memberitahukan janji Allah dalam memulihkan keberadaan dan kepribadiannya "Aku telah melihat segala jalannya itu, tetapi Aku akan

\footnotetext{
${ }^{15}$ John Baker, 8 Pilihan Hidup Bahagia..., 17-19

${ }^{16}$ ueu5783.weblog.esaunggul.ac.id/teori-psikologi-tentang-manusia, diakses 28 Mei 2017
} 
menyembuhkan dan akan menuntun dia dan akan memulihkan dia dengan penghiburan; juga pada bibir orang-orangnya yang berkabung" Yesaya 57:18-19.

\section{Karya Keselamatan Dalam Tuhan Yesus}

Bagian dari proses pendewasaan sebagai orang percaya adalah kemampuan untuk melihat konsep diri yang baru dalam Kristus, yang telah diciptakan ulang seturut dan dalam gambaran Allah untuk kehidupan yang baru (lih. Ef. 4:21-24; Kol. 3:9-11). Ada 3 cara yang bisa diperhatikan dari setiap individu yang memiliki konsep diri dalam Kristus yaitu;

1). Cara untuk mencintai diri berdasarkan latar belakang agama, suku, atau status sosial bukanlah kebencian terhadap diri sendiri atau penolakan atas nilai diri, namun kesadaran akandi mana dan bagaimana nilai konsep diri tersebut diperoleh melalui anugerah Tuhan melalui Yesus Kristus.

2). Cara untuk menghargai diri (berdasar status sosial, performa, penampilan, latar belakang agama, dll) bukanlah penyangkalan diri, melainkan pemahaman dan penerimaan anugerah dan kecukupan yang diberikan-Nya pada manusia dalam Kristus yang adalah satu-satunya yang memberikan makna dan nilai yang sejati.

3) Cara untuk memenuhi diri bukanlah hidup yang tanpa arti dan tujuan, melainkan hidup yang sepenuhnya terpikat dalam Tuhan dan tujuan-Nya sehingga pemenuhan diri dapat dicapai secara alami (atau rohani) melalui hubungan dan keterlibatan dengan Tuhan Yesus, bukan dalam keasyikan akan diri sendiri.

Allah begitu mengasihi manusia, sehingga Ia mengutus anak-Nya supaya manusia diselamatkan dan diperdamaikan dari dosa, dan menarik manusia kepada-Nya ke dalam hubungan abadi termasuk kehidupan kekal (Yohanes 3:16).

\section{Membangun Konsep Diri Berdasarkan Alkitab}

Bila berpijak pada definisi konsep diri adalah "memandang diri" sebagaimana Allah memandang diri kita sendiri - tidak lebih tidak kurang, maka untuk membangun konsep diri yang benar: pertama, harus mengenal dan mempercayai Allah secara pribadi melalui Yesus Kristus; kedua, menyerap karakter Tuhan dan mempelajari Firman-Nya; ketiga, membiarkan orang-orang Kristen lain membantu dirinya membentuk pemahaman diri. Maka membangun konsep diri merupakan hal yang sangat penting, karena hal ini akan membuat seseorang menjalani kehidupan ini dengan mantap, tidak terpengaruh oleh dunia bahkan perkataan-perkataan orang lain.

Membangun konsep diri menurut Nicholas; Konsep diri yang seimbang adalah antara keseluruhan dan kerendahan. Di satu sisi manusia itu adalah citra yang rendah, hanya tersusun dari debu tanah (Kej. 2:7) dan hanya sebuah citra (image). Namun di pihak lain, gambar itu bukan sembarang gambar tetapi gambar Allah (Kej. 1:27) yang menunjukkan adanya suatu keluhuran (dignity). Manusia Kristen dirancang untuk satu dignity yang bernilai, berharga dan pada akhirnya akan dimuliakan dalam peristiwa 
pemuliaan. ${ }^{17}$ Karena itu manusia dapat menemukan dan membangun konsep diri seperti persfektif Allah kembali.

Konsep diri bukanlah bawaan dari lahir termasuk konsep diri irasional, tapi pada tahapan tertentu setiap individu bisa mengalami konsep diri yang positif 'ideal', jika sudah diselesaikan atau ditangani dengan tepat. Untuk mengembangkan konsep diri berdasarkan konsep Alkitabiah yang bisa dilakukan dan dikembangkan oleh setiap individu untuk menemukan konsep diri dalam perspektif Tuhan, yaitu:

\section{Dalam Perjanjian Lama Dan Perjanjian Baru}

Hanya berdasarkan penyataan Alkitab yang bisa menjelaskan jawaban yang dibutuhkan dalam pemulihan pribadi yang mengalami persoalan termasukkonsep diri irasional untuk menemukan pengharapan dan arah yang harus dilakukan. Alkitab adalah satu-satu yang dapat dipercaya dan akurat untuk memberikan solusi. Bagian di bawah ini akan menguraikan langkah-langkah yang dilakukan kepada tokoh-tokoh Alkitab yang mengalami pemulihan

\section{Perjanjian Lama}

Ada banyak kejadian pada Alkitab di Perjanjian Lama yang menunjukan nilai-nilai untuk saling tolong menolong, saling menasehati, dan bukan saja antar sesama manusia, tetapi Allah sering kali dengan perantaraan malaikat-Nya pun turut aktif menolong umat-Nya.

Pada kitab Ayub, Elihu memberi nasehat kepada Ayub di tengah-tengah penderitaannya (Ayb. 32:1-32). Malaikat Tuhan menolong Elia ketika ia kesepian dan putus asa di padang gurun (1Raj.19:1-8). Daniel menasehati raja Nebukadnezar (Dan. 2), dan Daud memainkan kecapi untuk menghibur Saul yang murung dan gelisah (1Sam.19:9-1-10). Daud menerima dan merangkul Mefiboset untuk menikmati makanan raja bersama di meja makan.

Contoh kasus dari kitab Ayub; seorang konselor bernama Elihu (Ayub 32) dalam memberikan pemulihan kepada Ayub yang mengalami masalah yang dihadapi. Menurut E.P. Gintings prinsip yang bisa diambil dari Elihu sebagai seorang konselor adalah; 1) Elihu 'mendengar' (Ayat 11), 2) Elihu 'mengerti' (ayat 12), 3) Elihu 'menguatkan' (ayat 6-7), Elihu 'mengkonfrontasikan' (ayat 12), Elihu 'mengajar' (ayat 33), Elihu 'membimbing' pasal 34". 18

\section{Perjanjian Baru}

Dalam Perjanjian baru, Paulus sendiri memerintah para pemeluknya untuk saling menasehati (Rm. 15:14), nesehatilah seorang yang lain (Ibr. 3:13), hiburlah seorang akan yang lain dengan perkataan-perkataan ini (1Tes. 4:18), nasehatilah seorang akan yang lain dan saling membangunlah kamu (1Tes. 5:11), hendaklah kamu saling mengaku dosa

\footnotetext{
${ }^{17}$ Nicholas Kurniawan, "Membangun Konsep Diri Berdasarkan Firman Tuhan."Seminari Alkitab Asia Tenggara Veritas Journal Vol.1/ No. 2, (Malang : 2000), 215-222

${ }^{18}$ E.P. Gintings, Konseling Pastoral, (Bandung: Jurnal Info Media, 2009), 27-29
} 
dan saling mendoakan, supaya kamu sembuh (Yak. 5:16). Adapun kata-kata bahasa Yunani yang berhubungan dengan pengertian konseling, secara khusus pada surat Rasul Paulus kepada jemaat di Tesalonika.

"Kami juga menasehati (parakaleo) kamu, saudara-saudara, tegorlah (nouthetheo) mereka yang hidup dengan tidak tertib, hiburlah (paramutheomai) mereka yang tawar hati, belalah (antechomai) mereka yang lamah, sabarlah (makrothumeo) terhadap semua orang" (1 Tes.5:14). Arti dari bahasa Yunani yang dipakai adalah sebagai berikut: Parakaleo memiliki arti menasehati, mendorong, mendukung, menghibur (Rm.12:1; 15:30; 2 Kor. 1:4). Nouthetheoberarti memberi pengertian, mengigatkan, menegur (Rm.12:1;15:30; 2Kor. 1:4). Paramutheomai berarti menghibur, menguatkan (1Tes. 2:11). Antechomai berarti memberi perhatian, memegang teguh dan memegang erat, sedangkan makrothumeo berarti bersabar (Mat.18:26, 29; Ibr. 6:15; Yak.5:7). ${ }^{19}$

Prinsip-prinsip yang bisa diambil dari konseling Tuhan Yesus sebagai Penasehat yang ajaib (Yes 9:6) dari Lukas 24 yaitu: 1) Tuhan Yesus 'datang dan berjalan bersama mereka' ayat 15;2) Tuhan Yesus 'bertanya' ayat 17,19; 3) Tuhan Yesus 'mendengar' ayat 17 ; 4) Tuhan Yesus 'menerima'; 5) Tuhan Yesus 'menghadapkan mereka dengan persoalan yang sebenarnya' ayat 25-26; 6) Tuhan Yesus 'mengajar' ayat 27;7) Tuhan Yesus 'bersedia tinggal bersama mereka' ayat $28-29 .{ }^{20}$

\section{Persepsi Realitas Obyektif}

Konsep diri manusia dapat dibangun dengan cara memahami melalui persepsi realitas obyektif yaitu bahwa memandang dirinya dikasihi dan dkhususkan oleh Allah, dan tidak bergantung pada situasi dan keadaan diluar diri sendiri seperti penilian subyektif. Menurut Mary Setiawan, "melalui anugerah Tuhan yang mewahyukan segala sesuatu yang bersangkut paut dengan manusia, maka ketika mengenal Tuhan, manusia menemukan pengertian mengenai siapakah aku berdasarkan maksud dan tujuan Sang Pencipta bagi dirinya. Maka berdasarkanlandasan berpikir teosentris manusia bisa memaknai konsep diri manusia menurut iman Kristen." 21

Pengenalan diri adalah langkah awal yang diperlukan seorang manusia untuk dapat menjalankan kehidupan ini secara efektif, berdaya guna, danbermakna. Menurut Albert Denis:

Dengan demikian sejauh apa anda mengenal diri anda sejauh itulah anda memperlakukan diri anda dan lingkungan dimana anda berada. Dalam situasi kehidupan sehari-hari sering ditemui orang yang terlalu percaya diri hasilnya adalah menjadi manusia sombong, sulit menghargai orang lain, dan egosentris; atau terlalu rendahmenilai dirinya sehingga menjadi manusia minder, kehilangan

${ }^{19}$ Stephen Tanuwijaya, Bimbingan Konselor Kristen, (tk: Sekolah Tinggi Teologi International Philadelpia, 2004), 12

${ }^{20}$ E.P. Gintings, Konseling Pastoral..., 30-34

${ }^{21}$ Mary Setiawani dan Stephen Tong,Seni Membentuk Karakter Kristen: Hikmat Guru \& Ayah Bunda, (Surabaya: Momentum, 2010), 102 
identitas diri, sulit menghargai dirinya sendiri, bahkan hanya bisa mengasihani diri. Disisi lain, ada juga yang lebih mampu melihat kesalahan-kesalahan orang lain daripada kesalahan dirinya, hasilnya menjadi kritikus yang destruktif. Hidupnya hanyalah berpikir bahwa keadaan buruk yang terjadi pada dirinya merupakan akibat dari kesalahan orang lain, sementara dirinya selalu benar. Seperti yang dinyatakan oleh pepatah kuno bahwa: "Gajah di pelupuk mata tidak tampak, semut di seberang lautan tampak. "Mengapa terjadi demikian? Hal tersebut terbentuk dari cara manusia mengenal dirinya yang seringdisebut konsep diri. Pemahaman terhadap konsep diri akan menghantarkan manusia menjawab pertanyaannya sendiri mengenai "Siapakah Aku?",22

Kenyataan yang tidak bisa dibatalkan manusia, sejak manusia lahir dalam dunia bukan karena kemauan dirinya atau orang tua. Manusia tidak bisa menentukan lahir dari orang tua seperti apa yang ia mau, dari suku yang dipilih, keadaan keluarga dan ekonomi yang baik, yang jelas Tuhanlah yang menghadirkannya dalam dunia

\section{Menilai Diri Berdasarkan Penilaian Tuhan}

Alkitab secara konsisten mengatakan manusia berharga, karena manusia diciptakan menurut gambar dan rupa Allah (Kej 1:26-27) dan Allah memelihara dan mengasihi umat-Nya sebagai 'biji mata'-Nya (Ul. 32:10). Allah membenci dosa manusia tetapi Allah tidak membenci manusia. Ia tetap menunjukkan kasih-Nya bahkan ketika manusia masih berdosa (Roma 5:8). Setiap orang dapat memiliki harga diri yang baik dan positif bukan karena apa yang telah diperbuat dan bukan karena keberadaannya sebagai manusia, namun semata-mata karena Anugerah Allah dan karunia keselamatan yang diberikan-Nya (Gal. 6:14; Roma 15:17).

Oleh karena itu, ketika seseorang mengalami gangguan dalam konsep diri; ia bisa bangkit dan dipulihkan karena Allah (Allah memiliki kuasa untuk mengubah keadaan seseorang). Caranya menurut John Baker "bersedia percaya dan menerima Allah; pertama mempercayai tiga kebenaran tentang Allah seperti percaya bahwa Allah itu ada, percaya bahwa anda berarti bagi Dia, percaya bahwa Dia berkuasa untuk menolong anda. Kedua, terimalah Dia dalam hidup "Filipi 2:13."23 Dampak dari pemulihan itu mengakibatkan seseorang yang irasional menjadi rasional. Konsep diri yang sudah mengalami pembaharuan dan kesembuhan, yang membawa dirinya mampu menilai diri dengan kebenaran firman Tuhan.

\section{Keseimbangan Realita Dan Rohani}

Berdasarkan pandangan Kristen makna dan pemaknaan mengenai konsep diri memiliki pengertian yang lebih mendalam dibandingkan dengan kajian apapun didalam sejarah. ${ }^{24}$

${ }^{22}$ Albret Denise \& Peterfreund Albert, Great Tradition in Ethics, (New York: D.Van Nostrand Company, 1980), p.v-vi.

${ }^{23}$ John Baker, 8 Pilihan..., 59-60

24 Seseorang yang hanya melihat keluar dan tidak mencermati diri sendiri, tidak akan pernahmenjadi seorang manusia yang manusiawi dan berkarakter agung. Introspeksi (koreksi) diri danpengenalan diri merupakan salah satu tugas penting di dalam membentuk kehidupan, sebabpengenalan terhadap 
Seseorang tidak mungkin mengenal diri, kecuali orang tersebut mengenal Allah terlebih dahulu.

Pernyataan iman Kristen dalam Amsal 1:7 tertuliskan: "Takut akan TUHAN adalah permulaan pengetahuan, tetapi orang bodoh menghina hikmat dan didikan." Mengenal dan menghormati Allah merupakan titik awal dari hikmat, bijaksana yang tertinggi. Manusia harus mengenal Allah sehingga manusia bisa menerima keberadaan dirinya dalam konsep diri yang benar.

Oleh karena itu keseimbangan realita dan rohani dapat terbentuk dengan terus memegang prinsip dari 2 Korintus 5:17 "Jadi siapa yang ada dalam Kristus, ia adalah ciptaan baru: yang lama sudah berlalu, sesungguhnya yang baru sudah datang." Proses ini dapat dilihat dari Allah telah mengubah; saat seseorang percaya Kristus diberi hidup baru, hasrat baru, dan identitas baru sebagai anak-anak Allah (Efesus 2:4-5; Yohanes 1:12). Lalu saat seseorang menjalani kehidupan tetap diubah; sedang dijadikan serupa dengan Allah (Kolose 3:8-10).

\section{Hakekat Konsep Diri Irasional}

\section{Terminologi Konsep Diri Irasional Kaum Muda}

\section{Konsep Diri Irasioanal}

Manusia pada dasarnya tidak hanya melakukan persepsi terhadap orang lain, tetapi juga mempersepsi diri sendiri. Saat mempersepsi diri sendiri itu, diri sendiri menjadi subjek dan objek persepsi sekaligus. Konsep diri adalah pikiran dan keyakinan seseorang mengenai dirinya sendiri. Orang yang memiliki konsep diri irasional juga cenderung menilai orang lain secara salah dan subyektif. Beberapa definisi dari kata Konsep diri yaitu:

Konsep diri dianggap sebagai komponen kognitif (pengetahuan) dari diri sosial secara keseluruhan, yang memberikan penjelasan tentang bagaimana seorang manusia memahami perilaku, emosi, dan motivasinya sendiri. Hal ini merupakan jumlah keseluruhan dari keyakinan individu tentang dirinya sendiri. Sedangkan Calhoun dan Acocella menuliskan bahwa konsepdiri adalah pandangan manusia tentang diri sendiri, yang meliputi dimensi: pengetahuan tentang dirisendiri, pengharapan mengenai diri sendiri, dan penilaian tentang diri sendiri baik secara fisik, psikis, sosial, intelektual, moral, maupun spiritual. Pandangan ini diperoleh manusia dari pengalamannya berinteraksi dengan orang lain yang mempunyai arti penting dalam hidupnya. ${ }^{25}$

diri sendiri merupakan prinsip kemanusiaan yang penting dan mendasar. Halini diujarkan oleh seorang filsuf besar dari Yunani bernama Sokrates kurang lebih 4 abad SM,pernyataannya: "Ketahuilah dirimu, karena disitulah permulaan pengetahuan." Makna pernyataantersebut sangat mendalam bagi manusia dan kehidupannya, apa gunanya mengetahui segalasesuatu, tetapi tidak mengetahui diri sendiri. Pengetahuan bukan di luar, tetapi pengetahuan dimulaidari pengenalan tentang diri sendiri. Maka untuk mengetahui, harus dimulai dari pengenalan akandiri sendiri.

${ }^{25}$ Elizabeth B. Hurlock,Personality Development, (New York: McGraw-Hill Book Company, 1974), 24 
Sikap irasional seperti permitif dan apatis. Kesadaran tentang konsep diri diterima secara irasional untuk menutupi dirinya sendiri. Misalnya seseorang menilai dirinya misalnya dari fisik; fisiknya tidak terlalu kurus dan tidak terlalu gemuk, tapi karena sudah berpikir irasional, dirinya menyatakan gemuk dan sangat menjijikkan. Ronald W.Leigh menjelaskan bahwa:

Jika konsep diri seseorang 'irasional', pernyataan-pernyatan dan tindakannya akan tampak tidak rasional bagi orang lain. Kalau konsep dirinya rendah (artinya, kalau ia menganggap dirinya mempunyai sedikit kemampuan saja) mungkin ia akan menghindari tanggung jawab atau mengandalkan orang lain untuk mengambil inisiatif. Kalau ia menilai dirinya terlalu tinggi, mungkin ia akan memperlakukan orang lain dalam sikap yang merendahkan dan menjengkelkan, atau memperhatikan kerendahan hati yang palsu. Kalau ia menilai dirinya tidak cukup tinggi, ia mungkin akan bersikap tertutup atau berpandangan yang sebaliknya. ${ }^{26}$

Jadi dari terminologi, konsep diri irasional adalah seseorang memandang dirinya sendiri yang terkadang akan berbeda dari pandangan orang lain. Dimana konsep diri adalah gagasan mengenai diri sendiri yang mencakup keyakinan, pandangan, serta penilaian seseorang terhadap dirinya sendiri. Dan konsep diri yang dinilai tidak didasarkan pada akal atau pikiran, landasan pemikiran realistis dan rasional.

\section{Pandangan Dan Pendekatan Para Ahli Psikologi}

Adapun beberapa pandangan dari para ahli mengenai konsep diri di antaranya:

Menurut Hurlock, konsep diri adalah konsep seseorang dari siapa dan apa dia itu. Konsep ini merupakan bayangan cermin, ditentukan sebagian besar oleh peran dan hubungan dengan orang lain, dan apa yang kiranya reaksi orang lain terhadapnya. Konsep diri mencakup citra diri fisik dan psikologis. Citra diri fisik biasanya berkaitan dengan penampilan, sedangkan citra diri psikologis berdasarkan atas pikiran, perasaan, dan emosi. ${ }^{27}$ Song dan Hattie mengemukakan bahwa konsep diri terdiri atas konsep diri akademis dan non akademis. Selanjutnya konsep diri non akademis dapat dibedakan menjadi konsep diri sosial dan penampilan diri. Jadi menurut Song dan Hattie, konsep diri secara umum dapat dibedakan menjadi konsep diri akademis, konsep diri sosial, dan penampilan diri. ${ }^{28}$ Menurut Burns, konsep diri adalah suatu gambaran campuran dari apa yang kita pikirkan, orang-orang lain berpendapat mengenai diri kita, dan seperti apa diri yang kita inginkan. ${ }^{29}$ Menurut William D. Brooks, konsep diri merupakan persepsi individu terhadap dirinya sendiri yang bersifat psikis dan sosial sebagai hasil interaksi dengan orang lain. ${ }^{30}$

Rational Emotive Behavior Therapy dilakukan dengan menggunakan prosedur yang bervariasi dan sistematis yang secara khusus dimaksudkan untuk mengubah tingkah laku dalam

\footnotetext{
${ }^{26}$ Ronald W.Leigh, Mengenal Dengan Efektif, (Jakarta: BPK Gunung Mulia, 1991) 52-53

${ }^{27}$ Hurlock B, Psikologi Perkembangan Anak Jilid 2. (Jakarta: Erlangga, 2005), 237

${ }^{28}$ weebly.com/sekilas-tentang-konsep-diri.html, diakses 26 Mei 2017

${ }^{29}$ weebly.com/sekilas-tentang-konsep-diri.html, diakses 26 Mei 2017

${ }^{30}$ Jalaluddin Rahmat , Psikologi..., 100
} 
batas-batas tujuan yang disusun secara bersama-sama oleh konselor dan konseli. Karakteristik proses Rational Emotive Behavior Therapy adalah sebagai berikut: 1. Aktif-direktif, artinya bahwa dalam hubungan konseling konselor lebih aktif membantu mengarahkan konseli dalam menghadapi dan memecahkan masalahnya. 2. Kognitif-eksperiensial, artinya bahwa hubungan yang dibentuk berfokus pada aspek kognitif dari konseli dan berintikan pemecahan masalah yang rasional. 3. Emotif-ekspreriensial, artinya bahwa hubungan konseling yang dikembangkan juga memfokuskan pada aspek emosi konseli dengan mempelajari sumber-sumber gangguan emosional, sekaligus membongkar akar-akar keyakinan yang keliru yang mendasari gangguan tersebut. 4. Behavioristik, artinya bahwa hubungan konseling yang dikembangkan hendaknya menyentuh dan mendorong terjadinya perubahan tingkah laku konseli. ${ }^{31}$

Tujuan umum Rational Emotive Behavior Therapy adalah mengajari konseli bagaimana cara memisahkan evaluasi perilaku mereka dari evaluasi diri - esensi dan totalitasnya - dan bagaimana cara menerima dengan segala kekurangannya. Sedangkan tujuan dasarnya adalah mengajarkan konseli bagaimana merubah disfungsional emosi dan perilaku mereka menjadi pribadi yang sehat. Sikap, peran dan tugas konselor menurut Corey konselor yang menggunakan pendekatan Rational Emotive Behavior Therapy memiliki tugas spesifik. Tahap pertama adalah konselor menunjukkan pada konseli bahwa dalam pikirannya saat ini terlalu banyak pikiran-pikiran yang irasional seperti "harus", sebaiknya", dan "seharusnya". Konselor mendorong dan sering membujuk konseli agar melakukan aktivitas yang akan menyembunyikan keyakinan pengalahan diri mereka. Tahap kedua adalah mendemonstrasikan bahwa konseli mempertahankan gangguan emosi mereka aktif dengan meneruskan berpikir secara tidak logis dan realistis. Tahap ketiga adalah membantu konseli memodifikasi pemikiran dan mengabaikan gagasan irasional mereka. Konselor membantu konseli memahami pikiran irasional yang menyalahkan diri sendiri dan juga mengubah perilaku menyalahkan diri. Tahap keempat adalah menantang konseli untuk mengembangkan filosofis hidup yang rasional sehingga di masa depan mereka mampu menghindari diri agar tidak menjadi korban keyakinan irasional yang lain. ${ }^{32}$ Teknik-teknik Kognitif - Disputing irrational beliefs Metode kognitif dalam Rational Emotive Beh

\section{Kaum Muda}

Masa Pemuda dikategorikan umur 18-25 bahkan sampai umur 30 tahun, masa ini disebut juga masa dewasa (muda). ${ }^{33}$ Menurut Erickson dalam buku E.P.Gintings, dalam fase ini apabila seorang muda tidak mampu berelasi intim terhadap seseorang, ia juga tidak mungkin berelasi intim dengan banyak orang. ${ }^{34}$ Ada beberapa ciri masa pemuda yaitu:

1. Pemuda penuh dinamika gelora hidup dan semangat juang yang sedang tumbuh. Hal ini mendorongnya mencari bentuk-bentuk penyaluran. Ia tidak suka terkungkung, tidak mau diam, dan sulit merasa puas.

\footnotetext{
${ }^{31}$ https://iruyuriruy.wordpress.com/rational-emotive-therapy-albert-ellis/, diakses 26 Mei 2017

${ }^{32}$ https://iruyuriruy.wordpress.com/rational-emotive-therapy-albert-ellis/ diakses 26 Mei 2017

${ }^{33}$ Informan yang usia 22-28 tahun ada yang kuliah dan bekerja.
} 
2. Semangat berpetualang mendorongnya muda mencoba nilai-nilai yang baru. Ia tidak suka digurui atau didikte, dan berkeinginan untuk melakukan pembaharuan (tidak mau terpaku kepada hal-hal yang mapan atau biasa).

3. Perkembangan intelek dan emosinya bersikap selektif atau kritis. Ia mencari hal yang cocok sesuai cita rasa yang ada padanya atau dengan cara berikir dan nilainya sendiri.

4. Tumbuh sikap mau menjadi pahlawan dan mudah mengkultuskan tokoh yang menjadi idolanya. Ia mau diajak berjuang di garis depan.

5. Masa pembangunan untuk mencari dan menemukan identitasnya. Ia berada dalam suasana terombang-ambing. ${ }^{35}$

Melihat ciri utama kaum muda itu maka bisa dimengerti bahwa kaum muda dan usia muda mempunyai arti kepentingan tersendiri. Alkitab menjelaskan tentang karateristik kaum muda seperti Amsal 22:6 "Didiklah orang muda menurut jalan yang patut baginya, maka pada masa tuanya pun ia tidak akan menyimpang dari pada jalan itu". Masa muda, inilah satu periode transisi seorang manusia dari masa kanak-kanak menuju masa dewasa. Inilah waktu di mana seseorang memiliki perkembangan yang pesat akan pemikiran abstrak, penemuan identitas diri secara psikologis, dan keinginan untuk dapat hidup mandiri. Inilah suatu masa di mana seseorang dipenuhi dengan kekuatan dan vitalitas, sekaligus menghadapi badai, konflik, dan stress. Inilah satu periode dalam hidup manusia ketika aspek kekuatan fisik menjadi begitu memuncak.

Dari perspektif Amsal 22 dan Kitab Pengkhotbah, masa muda adalah waktu-waktu krusial di mana seseorang menetapkan fondasi, jalan, dan arah hidupnya. Inilah masa di mana seseorang seharusnya menerima seluruh pengajaran dan prinsip kebenaran yang akan terus ia pegang erat seumur hidup. Jika masa tersebut diisi dengan segala hal yang berharga, berbobot, dan bermutu, maka arah hidup orang tersebut akan jelas dan bahkan sampai masa tua ia akan tetap mengikuti jalan tersebut (1Timotius 4:12).

\section{Pembentukan Konsep Diri Irasional}

Konsep diri adalah semua perasaan, kepercayaan dan nilai yang diketahui individu tentang dirinya dan mempengaruhi individu dalam berhubungan dengan orang lain. Keempat komponen konsep diri adalah identitas, citra tubuh, harga diri dan peran. ${ }^{36}$ Konsep diri adalah kombinasi dinamis yang dibentuk selama bertahun-tahun dan didasarkan pada hal berikut: a.Reaksi orang lain terhadap tubuh seseorang; b.Persepsi berkelanjutan tentang reaksi orang lain terhadap dirinya;c.Hubungan dengan diri dan orang lain;d.Struktur kepribadian;e. Persepsi terhadap stimulus yang mempunyai dampak pada diri;f. Pengalaman baru atau sebelumnya;g. Perasaan saat ini tentang fisik, emosional dan sosial diri;h. Harapan tentang diri. ${ }^{37}$

Konsep diri mempunyai sifat yang dinamis, artinya tidak luput dari perubahan. Ada aspek-aspek yang bisa bertahan dalam jangka waktu tertentu, namun ada juga yang

\footnotetext{
${ }^{35}$ E.P.Gintings, Pastoral ..., 15-16

${ }^{36}$ ueu5783.weblog.esaunggul.ac.id/konsep-diri, diakses 28 Mei 2017

${ }^{37}$ blognyadevizulkarnain.blogspot.com/pembentukan-konsep-diri.htm, diakses 28 Mei 2017
} 
mudah sekali berubah sesuai dengan situasi sesaat. Dalam konsep diri ini terdapat beberapa unsur antara lain:

1. Penilaian diri merupakan pandangan diri terhadap:

- Pengendalian keinginan dan dorongan-dorongan dalam diri. Bagaimana kita mengetahui dan mengendalikan dorongan, kebutuhan dan perasaan perasaan dalam diri kita.

- Suasana hati yang sedang kita hayati seperti bahagia, sedih atau cemas. Keadaan ini akan mempengaruhi konsep diri kita positif atau negatif.

- Bayangan subyektif terhadap kondisi tubuh kita. Konsep diri yang positif akan dimiliki kalau merasa puas (menerima) keadaan fisik diri sendiri.Sebaliknya, kalau merasa tidak puas dan menilai buruk keadaan fisik sendiri maka konsep diri juga negatif atau akan jadi memiliki perasaan rendah diri.

2. Penilaian sosial merupakan evaluasi terhadap bagaimana individu menerima penilaian lingkungan sosial pada dirinya. Penilaian sosial terhadap diri yang cerdas, supel akan mampu meningkatkan konsep diri dan kepercayaan diri. Adapun pandangan lingkungan pada individu seperti si gendut, si bodoh atau si nakal akan menyebabkan individu memiliki konsep diri yang buruk terhadap dirinya.

3. Konsep lain yang terdapat dalam pengertian konsep diri adalah self image atau citra diri, yaitu merupakan gambaran:

- Siapa saya, yaitu bagaimana kita menilai keadaan pribadi seperti tingkat kecerdasan, status sosial ekonomi keluarga atau peran lingkungan sosial kita.

- Saya ingin jadi apa, kita memiliki harapan-harapan dan cita-cita ideal yang ingin dicapai yang cenderung tidak realistis. Bayang-bayang kita mengenai ingin jadi apa nantinya, tanpa disadari sangatdipengaruhi oleh tokoh-tokoh ideal yang menjadi idola, baik itu ada di lingkungan kita atau tokoh fantasi kita.

- Bagaimana orang lain memandang saya, pertanyaan ini menunjukkan pada perasaan keberartian diri kita bagi lingkungan sosial maupun bagi diri kita sendiri. Konsep diri yang terbentuk pada diri juga akan menentukan penghargaan yang diberikan pada diri. Penghargaan terhadap diri atau yang lebih dikenal dengan self steem ini meliputi penghargaan terhadap diri sebagai manusia yang memiliki tempat di lingkungan sosial. Penghargaan ini akan mempengaruhi dalam berinteraksi dengan orang lain. ${ }^{38}$

Pembentukan konsep diri sangat mempengaruhi setiap individual dalam menentukan tindakan baik dari sendiri atau untuk menunjukkan dirinya sendiri seperti apa yang diputuskan atas dasar penilaian yang diluar pemikirannya 'irasional'.

Faktor-Faktor Yang Mempengaruhi Konsep Diri Irasional

Berbagai faktor dapat mempengaruhi proses pembentukan konsep diri seseorang. Secara umum konsep diri dipengaruhi oleh orang lain dan kelompok rujukan. Manusia

${ }^{38}$ ueu5783.weblog.esaunggul.ac.id/konsep-diri, 28 Mei 2017 
mengenal dirinya secara kodrati didahului oleh pengenalan terhadap orang lain terlebih dahulu, namun tidak semua orang mempunyai pengaruh yang sama.

Yang paling berpengaruh adalah orang lain yang paling dekat dengan diri kita yang terbagi 3 golongan, yaitu: Golongan pertama disebut sebagai significant others, yaitu orang tua dan saudara. Golongan ke dua disebut sebagai affective others yaitu orang lain yang memiliki ikatan emosional seperti sahabat karib. Golongan ke tiga disebut sebagai generalized others yaitu keseluruhan dari orang-orang yang dianggap memberikan penilaian terhadap diri sendiri. Sementara kelompok rujukan mempengaruhi konsep diri karena ikatan-ikatan norma-norma yang dilekatkan pada diri manusia. ${ }^{39}$ Menurut Stuart dan Sudeen ada beberapa faktor-faktor yang mempengaruhi perkembangan konsep diri. Faktor-foktor tersebut terdiri dari teori perkembangan, Significant Other (orang yang terpenting atauyang terdekat) dan Self Perception (persepsi diri sendiri).1. Teori perkembangan. Konsep diri belum ada waktu lahir, kemudian berkembang secara bertahap sejak lahir seperti mulai mengenal dan membedakan dirinya dan orang lain. Dalam melakukan kegiatannya memiliki batasan diri yang terpisah dari lingkungan dan berkembang melalui kegiatan eksplorasi lingkungan melalui bahasa, pengalaman atau pengenalan tubuh, nama panggilan, pangalaman budaya dan hubungan interpersonal, kemampuan pada area tertentu yang dinilai oleh diri sendiri atau masyarakat serta aktualisasi diri dengan merealisasi potensi yang nyata. Ronald W.Leigh menjelaskan bahwa:

Konsep diri dan harga diri seseorang sesungguhnya masuk ke dalam setiap pikiran dan tindakan. Kalau konsep diri seseorang tidak tepat, pernyataanpernyataan dan tindakannya akan tampak tidak rasional bagi orang lain. Kalau konsep dirinya rendah mungkin ia akan menghindari tanggung jawab atau mengandalkan orang lain untuk mengambil inisiatif. Kalau ia menilai dirinya terlalu tingggi mungkin ia akan memperlakukan orang lain dalam sikap yang merendahkan dan menjengkelkan atau memperlihatkan kerendahan hati yang palsu. Kalau ia menilai dirinya tidak cukup tinggi, ia mungkin akan bersikap tertutup atau berpandangan yang sebaliknya. ${ }^{40}$

Berdasarkan pernyataan-pernyataan di atas, dapat disimpulkan bahwa konsep diri tersebut dapat dipengaruhi oleh berbagai faktor, baik itu faktor dari dalam individu itu sendiri maupun diluar diri sendiri seperti keadaan fisik, keadaan keluarga, persepsi orang terhadap dirinya, tuntutan orang tua terhadap anak, orang-orang yang dekat dalam lingkungan, dan persepsinya terhadap keberhasilan dan kegagalan.

Di bawah ini akan diuraikan faktor-faktor yang mempengaruhi konsep diri irasional pada diri seseorang untuk bahan acuan penelitian yang dilakukan peneliti, yaitu:

\footnotetext{
${ }^{39}$ ueu5783.weblog.esaunggul.ac.id/konsep-diri, 20 Mei 2017

${ }^{40}$ Ronald.W.Leigh, Melayani..., 52.
} 


\section{Pola Asuh Orang Tua}

Pola asuh orang tua menjadi faktor yang signifikan dalammempengaruhi konsep diri yang terbentuk. Sikap positif orangtua akan menumbuhkan konsep dan pemikiran yang positif sertasikap menghargai diri sendiri. Sikap negatif orang tua akan mengundang pertanyaan pada anak dan menimbulkan asumsi bahwadirinya tidak cukup berharga untuk disayangi dan dihargai.

Pola asuh orang tua merupakan pola perilaku yang diterapkan pada anak bersifat relatif konsisten dari waktu ke waktu. Pola perilaku ini dirasakan oleh anak, dari segi negatif maupun positif. Pola asuh yang ditanamkan tiap keluarga berbeda, hal ini tergantung pandangan dari tiap orang tua. ${ }^{41}$ Menurut Baumrind terdapat empat macam pola asuh orang tua yaitu: Pola asuh demokratis, Pola asuh otoriter, Pola asuh permisif atau pemanja, Pola asuh tipe penelantar. Penjelasannya sebagai berikut:

a. Pola asuh demokratis. Adalah pola asuh yang memprioritaskan kepentingan anak akan tetapi tidak ragu-ragu mengendalikan mereka. Orang tua dengan pola asuh ini bersikap rasional, selalu mendasari tindakannya pada rasio atau pemikiranpemikiran. Orang tua yang demokratis memandang sama kewajiban hak orang tua dan anak, bersikap rasional dan selalu mendasari tindakannya pada rasio pemikiran.

b. Pola asuh otoriter. Adalah pola asuh yang merupakan kebalikan dari pola asuh demokratis yaitu cenderung menetapkan standar yang mutlak harus dituruti, biasanya disertai dengan ancaman-ancaman. Bentuk pola asuh ini menekan pada pengawasan orang tua atau kontrol yang ditunjukkan pada anak untuk mendapatkan kepatuhan dan ketaatan. Jadi orang tua yang otoriter sangat berkuasa terhadap anak, memegang kekuasaan tertinggi serta mengharuskan anak patuh pada perintah-perintahnya.

c. Pola asuh permisif atau pemanja. Merupakan suatu bentuk pengasuhan dimana orang tua memberikan kebebasan sebanyak mungkin kepada anak untuk mengatur dirinya, anak tidak dituntut untuk bertanggung jawab dan tidak banyak kontrol oleh orang tua.

d. Pola asuh tipe penelantar. Pola asuh ini biasanya memiliki interaksi waktu yang sedikit dengan anak-anaknya. ${ }^{42}$

Faktor pola asuh orang tua menentukan konsep diri pada anak; menjadi anak yang memiliki konsep diri rasional atau konsep diri irasional.

\section{Kegagalan}

Sebenarnya kegagalan adalah hal yang biasa. Namun bagi pribadi yang memiliki konsep diri irasional kegagalan mempengaruhi seluruh aspek kehidupannya. Kegagalan yang terus menerus dialami seringkali menimbulkan pertanyaan pada diri sendiri dan berakhir pada kesimpulan bahwa penyebabnya terletak pada kelemahan diri. Kegagalan

\footnotetext{
${ }^{41}$ desysuar.blogspot.com/pola-asuh-orang-tua.html, 29 Mei 2017

42 desysuar.blogspot.com/pola-asuh-orang-tua.html, 29 Mei 2017
} 
membuat orang merasa tidak berguna. Tidak jarang orang yang merasa gagal terjebak pada penilaian negatif terhadap dirinya sendiri, misalnya bunuh diri. ${ }^{43}$

\section{Kritik Internal}

Manusia memiliki kebutuhan dasar yang menjadi standar dalam menilai dirinya. Menurut E.P.Ginting

Kebutuhan untuk dihargai merupakan kebutuhan dasar hidup manusia. Need for positive regard adalah kebutuhan dasar manusia yang perlu diperhatikan dan dipenuhi. Manusia membutuhkan kehangatan, penghangatan, penerimaan, pengagungan, dan dicintai dari orang lain serta sanggup mencintai orang lain. Kebutuhan dasar inilah bila dipenuhi akan membantu aktualisasi diri seseorang dengan menciptakan keselarasan antara konsep diri dan pengalaman". 44

Atau menjadi sebaliknya. Disinilah letak seseorang mengalami konsep diri ketika kritik internal menganggu kebutuhan dasarnya. Kadang kritik memang dibutuhkan untuk menyadarkan seseorang atas perbuatan yang dilakukan. Kritik terhadap diri sendiri berfungsi sebagai rambu-rambu dalam bertindak dan berperilaku agar keberadaan bisa diterima dan dapat beradaptasi. Walaupun begitu, kritik diri yang berlebihan dapat mengakibatkan individu menjadi rendah diri. ${ }^{45}$

\section{Penampilan}

Seorang pemudi yang memiliki cacat dalam tubuhnya sangat menganggu dirinya sehingga membuat ia mempersalahkan orang tua karena sudah melahirkan dan membuat ia menutup diri terhadap orang lain dan Tuhan. Seorang yang memperhatikan penilaian terhadap penampilan diri, sangat sulit untuk mengakui kelemahan dan kelebihan dirinya; selalu saja ada yang salah. Penilaian Fu Xie dan Jarot Wijanarko, “Tetapi orang-orang yang punya gambar diri buruk memiliki rasa malu yang berlebihan. Mereka takut untuk tampil ke depan dalam acara-acara pertemuan. Mereka malu kalau kelemahannya atau kekurangannya diketahui orang. Mereka juga malu keadaan dirinya diketahui orang lain." $" 46$

\section{Status Sosial Dan Ekonomi}

Masing-masing orang memiliki konsep diri yang berbeda-beda sehingga menyebabkan dirinya melakukan perbandingan diri dengan orang lain (Gejala ini disebut sebagai perbandingan sosial). Jika salah maka konsep diri irasional mengakibatkan dirinya tidak bisa bergaul 'minder' atau terbawa arus 'bukan menjadi dirinya supaya bisa diterima'.

${ }^{43}$ gitsalibeautyful.blogspot.com/konsep-diri-sebuah-strategi-mngenal.htm, 29 MEI 2017

${ }^{44}$ E.P.Ginting, Pastoral Konseling. Membaca..., 51.

${ }^{45}$ ueu5783.weblog.esaunggul.ac.id/teori-psikologi-tentang-manusia 29 Mei 2017

${ }^{46} \mathrm{Fu}$ Xie dan Jarot Wijanarko, Citra Diri, (Jakarta: Keluarga Indonesia, 2017), 41 


\section{Suku (Budaya)}

Melalui orang tua, pendidikan, latar belakang budaya, maka akan ditanamkan keyakinan, nilai, agama, ras, sifat nasional untuk membentuk konsep diri seseorang. Contohnya, ketika seseorang mempunyai latar belakang budaya yang baik dan memiliki etika maka orang tersebut memiliki konsep diri positif dan sebaliknya. ${ }^{47}$

Dari faktor-faktor yang mempengaruhi konsep diri irasional disebabkan karena setiap individu ingin memiliki makna diri namun menjadi persoalan ketika tuntutan untuk mendapatkan tidak sesuai dengan yang diharapkan. Tuntutan untuk memperoleh penghargaan diri misalnya "Karena ingin hidup berarti, sasaran-sasaran berbenturan, diperlakukan di bawah martabat, mengukur nilai diri untuk diakui, mengintimidasi dan mendominasi."

\section{Dampak - Dampak Konsep Diri Irasional}

\section{Psikologi - Sosiologis}

Psikologi - sosiolis mempelajari tentang perilaku dan juga pemikiran dari individu sedangkan pada kajian sosiologi fokus kepada kelompok-kelompok besar atau masyarakat sebagai satu kesatuan yang utuh. psikologi sosial berarti menitikberatkan pada kajian keilmuan yang membahas tentang kejiwaan seorang manusia yang dipengaruhi oleh hasil interaksi antar manusia dalam situasi sosial. Situasi sosial yang dimaksud adalah adanya kehadiran seseorang secara nyata ataupun imajinasi ${ }^{48}$ Bagian ini menjelaskan dampak yang dihadapi pribadi yang mengalami konsep diri irasional ketika berhadapan dengan dirinya di dalam lingkungan masyarakat yang berdekatan, yaitu;

\section{Peka Pada Kritik}

Kurangnya kemampuan untuk menerima kritik dari orang lain sebagai proses refleksi diri. Perasaaan subyektif bahwa setiap orang lain disekitarnya memandang dirinya dengan negatif. Akibatnya mengalami hambatan dalam interaksi dengan orang lain. E.P. Ginting katakan "orang yang mengalami luka batin biasanya memiliki konsep diri yang negatif. Pengalaman traumatis pada masa lalu membuatnya menganggap dirinya seperti sampah yang tidak berharga sama sekali. Ia dihantui perasaan bersalah melihat dirinya gagal dan layak menerima hukuman. Penolakan mengakibatkan seseorang merasa dirinya tidak dikasihi, diperhatikan, dan dibutuhkan oleh siapa pun". ${ }^{49}$

Orang yang merasa diri tak berharga akan merasa takut bahwa mereka akan diperdaya, ditolak, dan diremehkan dalam kehidupan. Namun dengan mengkhawatirkan hal yang paling buruk itu, mereka justru menciptakan apa yang mereka takuti. Mereka terperangkap ke dalam perilaku yang menghancurkan diri sendiri dan bersikap serba

\footnotetext{
${ }^{47}$ https://bagawanabiyasa.wordpress.com/konsep-diri-akademis/ 29 Mei 2017

${ }^{48}$ www.psikoma.com > Pendidikan, diakses 16 Juni 2018

${ }^{49}$ E. P.Ginting, Pastoral ..., 160
} 
curiga. Mereka berusaha untuk dapat diterima padahal mereka sendiri tidak percaya bahwa mereka layak diterima. ${ }^{50}$

Tanda-tanda orang yang peka pada kritik yaitu orang ini sangat tidak tahan kritik yang diterimanya dan mudah marah atau naik pitam, hal ini berarti dilihat dari individu tersebut belum dapat mengendalikan emosinya, sehingga kritikan dianggap sebagai hal yang salah. Bagi orang seperti ini koreksi sering dipersepsi sebagai usaha untuk menjatuhkan harga dirinya. Dalam berkomunikasi orang yang memiliki konsep diri negatif cenderung menghindari dialog terbuka, dan bersikeras mempertahankan pendapatnya dengan berbagai logika yang keliru.

\section{Responsif}

Bersikap yang berlebihan terhadap tindakan yang telah dilakukan, sehingga merasa segala tindakannya perlu mendapat penghargaan. Responsif terhadap pujian. Walaupun mungkin berpura-pura menghindari pujian, tidak dapat menyembunyikan antuasiasnya pada waktu menerima pujian. Buat orang seperti ini, segala macam embel-embel yang menjunjung harga dirinya menjadi pusat perhatian. Bersamaan dengan kesenangannya terhadap pujian, merekapun hiperkritis terhadap orang lain.Kesulitan terbesar dari pribadi yang mengalami dampak responsif ialah dirinya selalu menganggap paling benar dan pendapat atau masukan dari orang lain tidak dianggap jika dirinya merasa tidak nyaman. ${ }^{51}$

\section{Hiperkritis}

Hiperkritis mempunyai pengertian suka mengkritik (mengecam, mencela) sampai ke hal yang kecil-kecil, terlampau kritis. Pribadi yang mengalami hiperkritis disebabkan dirinya dalam lingkungan keluarga atau sekitarnya sering mengkritik dirinya yang berakibat pribadinya menjadi hiperkritis. Seorang hiperkritis pribadinya suka melakukan kritik negatif secara berlebihan terhadap orang lain.

Tanda yang dimiliki yaitu mengeluh, mencela, atau meremehkan apapun dan siapapun. Mereka tidak pandai dan tidak sanggup mengungkapkan penghargaan atau pengakuan pada kelebihan orang lain. ${ }^{52}$

\section{Pesimis}

Tandanya bersikap pesimis terhadap kompetisi. Orang yang pesimis adalah orang yang bersikap atau berpandangan tidak mempunyai harapan baik (khawatir) dan orang

${ }^{50}$ Mark Narramore, Menuju Citra Diri Kristus. (Jakarta:Bina Communio, 2000) 6.

${ }^{51}$ Mark Narramore, Menuju..., 8

${ }^{52}$ Kasus yang ditemukan dilapangan; peneliti memperhatikan dampak Hiperkritis yang dialami dari seorang pemuda sangat menganggu dirinya dengan orang tua - lingkungan. Semua perbuatan kasih dari ibunya dinilai negatif bahkan ia menjadi sangat benci dan mengeluarkan kata-kata kasar 'jahat'. Dengan persekutuan gereja-pemuda sudah tidak pernah hadir lagi; mempersalahkan dan menghindar 'semua dipandangannya salah bahkan ke pendeta, majelis, dan pengurus pemuda'. Tidak suka ditanya dan diberitahu karena ia sudah membentengi diri dengan keadaannya yang menurutnya baik dan benar. 
yang mudah putus harapan. Hal ini terungkap dalam keengganannya untuk bersaing dengan orang lain dalam membuat prestasi. Ia akan menganggap tidak akan berdaya melawan persaingan yang merugikan dirinya.

\section{Emosional}

Konflik emosional pada diri seseorang yang memiliki konsep diri irasional terjadi karena perasaan yang dihubungkan dengan pengalaman. June Hunt mengatakan:

Perasaan-perasaan itu terkait dengan kejadian-kejadian eksternal saat mereka dihubungkan dengan pkiran batiniah dan keadaan terpengaruh (preokupasi). Tandanya; mengalami kecemasan (saya tidak mengetahui siapa saya sebenarnya), depresi (saya tidak mempunyai harapan untuk masa depan), keraguan diri (saya begitu tidak sempurna), kesadaran diri (saya tidak dapat diterima dan dikasihi), dan harga diri rendah (saya tidak cukup baik)". ${ }^{53}$

Tandanya cenderung merasa tidak disenangi oleh orang lain. Ia merasa tidak diperhatikan, karena itulah ia bereaksi pada orang lain sebagai musuh, sehingga tidak dapat melahirkan kehangatan dan persahabatan, berarti individu tersebut rendah diri atau bahkan berperilaku yang tidak disenangi, misalnya membenci, mencela, atau bahkan yang melibatkan fisik yaitu mengajak berkelahi (bermusuhan).

\section{Psikis - Mentalitas}

Kesehatan mental yang baik adalah kondisi ketika batin seseorang berada dalam keadaan tentram dan tenang, sehingga memungkinkan untuk menikmati kehidupan sehari-hari dan menghargai orang lain di sekitar. Seseorang yang bermental sehat dapat menggunakan kemampuan atau potensi dirinya secara maksimal dalam menghadapi tantangan hidup, serta membentuk hubungan positif dengan orang lain. Namun sebaliknya, orang yang kesehatan mentalnya terganggu akan mengalami gangguan suasana hati, kemampuan berpikir, serta kendali emosi yang pada akhirnya bisa mengarah pada perilaku buruk.

Tidak mengherankan jika penyakit mental dapat menyebabkan masalah dalam kehidupan sehari-hari penderitanya, misalnya terganggunya interaksi atau hubungan mereka dengan orang lain.

\section{Strees}

Stres adalah keadaan ketika seseorang mengalami tekanan yang sangat berat, baik secara emosi maupun mental. Seseorang yang stres biasanya akan tampak gelisah, cemas, dan mudah tersinggung. Stres juga dapat mengganggu konsentrasi, mengurangi motivasi, dan pada kasus tertentu, memicu depresi.

Stres bukan saja dapat mempengaruhi psikologi penderitanya, tetapi juga dapat berdampak kepada cara bersikap dan kesehatan fisik mereka. Berikut ini adalah contoh dampak stres terhadap perilaku seseorang: Menjadi penyendiri dan enggan berinteraksi

${ }^{53}$ June Hunt, Pastoral Konseling Alkitabiah 2, (Jogyakarta: Yayasan Andi, 2015), 77 
dengan orang lain. Enggan makan atau makan secara berlebihan. Marah-marah dan terkadang kemaharan itu sulit dikendalikan, merokok, Mengonsumsi minuman beralkohol secara berlebihan. Penyalah gunaan obat-obat narkotika. ${ }^{54}$

\section{Kecanduan}

Tindakan negatif yang paling serius dari pribadi yang mengalami konsep diri irasional ketika ia tidak bisa menghadapi dirinya sendiri; berusaha mencari jalan pintas atau mencari kepuasan tersendiri 'kecanduan'. Kecanduan itu keterlibatan dengan kriminal dan perusakan diri serta memuaskan kekosongan diri misalnya judi, minumminuman keras dan obat-obatan terlarang. ${ }^{55}$ Serta bisa membuat seseorang menjadi pencinta atau kecanduan bekerja untuk menghindari lingkungan dan pandangan orang. ${ }^{56}$

\section{Depresi}

Depresi adalah kondisi mood (suasana hati) yang menurun drastis dan keengganan untuk melakukan aktivitas yang dapat mempengaruhi pikiran, perilaku, perasaan, dan kenyamanan. Depresi merupakan gangguan mental yang dapat mengontrol pikiran dan bisa menyebabkan hilangnya nafsu makan, susah tidur (insomnia), mood yang mudah berubah, dan rasa putus asa yang mendalam. Depresi adalah penyakit menyedihkan yang bisa mempengaruhi kondisi kehidupan sehari-hari dan bahkan bisa menghancurkan keharmonisan keluarga. ${ }^{57}$ J.L. Packer menjelaskan bahwa "Dikalangan umat percaya, kekecewaan bisa menghasilkan keputusasaan yang bisa menyebabkan depresi. Depresi merupakan kondisi jiwa dan raga yang kompleks, dan banyak faktor seperti temperamen, fisik, keadaan, dan rohani, yang bisa memunculkannya., ${ }^{, 5}$

\section{Etis - Teologis}

Dosa adalah penyebab disintegrasi struktur kepribadian manusia sehingga muncul konflik batin dalam kepribadian manusia. Allah sudah memperlengkapi jiwa manusia dengan pikiran untuk mampu membedakan yang baik dan buruk, adil dan tidak adil, agar dengan sorotan pikiran ia dapat melihat apa yang harus dikejar dan apa yang harus di jauhi.

Oleh karena itu, seseorang yang menderita tekanan dan konflik batin atau berhadapan dan dapat menyentuh realitas dosa, secara theologis, yang menjadi sumber terjadinya konflik batin adalah dosa (yang telah ada dalam diri manusia sebelum ia lahir), dosa yang diakibatkan ketidaktaatan dan ketidakpercayaan kepada Allah. Semua bidang gerak hidup manusia (rohani, pikiran, kemauan, kehendak dan fisik) tidak ada yang luput dari pengaruh dosa; sehingga terjadi kerusakan (disintegrasi).

\footnotetext{
${ }^{54}$ www.alodokter.com/kesehatan-mental, diakses 29 Mei 2017

${ }^{55}$ Sudah dialami oleh Cpl.01

${ }^{56} \mathrm{Cpl} .02$

57 J.L.Packer, God'S Plans For You, (Surabaya: Momentum, 2004), 201

${ }^{58}$ J.L.Packer, God'S Plans For You..., 201
} 
Dengan demikian setiap individu yang mengalami konsep diri irasional tidak bisa dilepaskan dari masalah etis-teologis dalam pribadinya. Dibawah ini ada dua dampak dari etis-teologis setiap individu yang mengalami konsep diri irasional, yaitu:

\section{Menjauhkan Diri Dari Persekutuan}

Pribadi yang mengalami konsep diri irasional dalam persekutuan dengan Tuhan dan gereja lokal 'anggota persekutuannya'; bisa saja dijadikan 'topeng'. Bisa saja ia menjadi pribadi yang rajin bersekutu tetapi yang sebenarnya ia sedang menutupi kenyataan sebenarnya dan mengharapkan sesuatu dari yang dilakukannya. Anthony A. Hoekema mengatakan bahwa "Orang yang memiliki konsep diri yang begitu negatif, yang menganggap dirinya sama sekali tidak berharga, takkan bisa secara efektif mengasihi sesamanya seperti dirinya sendiri; dia takkan berani memberikan dirinya kepada sesama di dalam persekutuan karena ia merasa tidak memiliki apa-apa yang berharga untuk diberikannya."59

Gangguan mental yang dialami pribadi yang salah memahami konsep dirinya; ia tidak bisa menerima dan merasakan kasih dan kebaikan Tuhan dalam kehidupannya.

\section{Mempersalahkan Tuhan}

Kesombongan rohani dan keminderan diri bisa membuat seseorang mempersalahkan Tuhan. Penilaian konsep diri irasional membawa seseorang; tidak bisa melihat tujuan rencana Allah dalam kehidupannya, ketidak-puasan dan kekurangan yang terjadi atau yang dialaminya disebabkan oleh Allah. Chester dan Betsy Kylstra mengatakan bahwa:

Trauma, tragedi, kondisi hidup yang sulit, dan doa yang tidak terjawab, semuanya dapat menyebabkan wajah dan hati kita berpaling dari Allah. Kepercayaan menjadi hancur dan keterasingan mulai menguasai. pencarian yang dilakukan tampaknya tidak memberikan hasil yang memuaskan. Ketika terjadi kekecewaan terhadap Allah, sangat sulit bagi seseorang berhubungan dengan Allah, apalagi untuk bertobat, karena ia telah terbiasa mempersalahkan Allah atas penderitaan yang dialaminya dalam hidup" ${ }^{60}$

Penyebab ketidakberartian dalam diri seseorang untuk menemukan pencarian konsep diri yang salah berdampak mempersalahkan Tuhan.

\section{Pemulihan Alkitabiah Terhadap Konsep Diri Irasional Kaum Muda}

Orang yang memimpin sesi pemulihan biasanya membawa orang yang dilayani kepada Allah sebagai Bapa yang mengasihi mereka, kepada Yesus sebagai Penasihat yang Ajaib, dan kepada Roh Kudus sebagai Penghibur dan Pembimbing mereka yang selalu hadir. Tuhan sendirilah yang menyatakan kebenaran-Nya yang membebaskan kita, dan kasih-Nya yang sempurna yang menyingkirkan segala ketakutan. Tentu saja,

59 Anthony A. Hoekema, Manusia Ciptaan Menurut Gambar Allah, (Surabaya:Momentum, 2003), 131.

${ }^{60}$ Chester dan Betsy Kylstra, Healing...,42 
konselor bisa memberikan nasihat dari firman Allah, tetapi akhirnya hadirat Allah yang memulihkan itulah yang mengubah kehidupan seseorang. ${ }^{61}$

Dalam pelayanan Gereja, khususnya contoh gereja di Saddleback, ada pelayanan khusus yang dipakai untuk membantu penanganan atas masalah-masalah kepribadian dan persoalan manusia yang diberikan nama program Celebrate Recovery 'Rayakan Pemulihan'. Pelayanan ini memakai pendekatan pertobatan dan pemulihan jiwa yang dikaji secara seimbang dan berimbang dari sudut pandangan Alkitabiah yang didirikan oleh John Baker. ${ }^{62}$ Sedangkan kebanyakan dari gereja-gereja lokal penanganan kepada seseorang yang mengalami konsep diri irasional melalui pelayanan konseling (pelayanan pribadi) dari sudut pandangan Alkitab.

\section{Tujuan Pemulihan Alkitabiah}

Pelayanan dalam Gereja untuk membawa umat Tuhan mengalami pemulihan rohani secara pribadi; tidak cukup hanya dengan menyampaikan firman Tuhan dalam khotbah, mengadakan KKR, Seminar-seminar tentang tema kebutuhan yang akan diselesaikan, reat-reat, atau memobilisasi pencarian jiwa baru, dan yang lainnya yang bersifat kelompok atau umum. Bons Strom menyatakan bahwa "tujuan penggembalaan bukanlah supaya gedung gereja penuh atau supaya gereja menjadi kudus, tetapi tujuan terakhir adalah supaya jemaat Yesus Kristus dibangun. Jika dalam jemaat tiap-tiap anggota menjadi anggota yang hidup, yang tahu akan panggilannya, maka jemaat itu akan menjadi jemaat yang hidup, suatu jemaat yang menarik seperti lampu diatas gunung." 63 Dalam hal ini, Gereja perlu mengadakan pelayanan khusus atau pribadi kepada umat Tuhan sebagai tolok ukur memperhatikan pertumbuhan kedewasaan rohani setiap pribadi umat Tuhan yang dilayani dalam hal ini bisa memakai model konseling "Pemulihan Alkitabiah'. Seperti yang Jay E. Adam katakan bahwa "tujuan konseling bersifat nouthetic yaitu; 1) Mencapai perubahan watak, 2) Menumbuhkan orang beriman dalam kebenaran, 3) membawa manusia mengasihi Allah dan ketetapanNya.,"

Setiap konselor (pada umumnya dalam gereja lokal adalah gembala jemaat); kadang kala berhadapan dengan konseli 'jemaat' yang mau terbuka datang kepada konselor untuk mendapatkan pendampingan 'konseling' dalam mengatasi masalah yang ada dalam dirinya. Namun ada kalanya seorang konselor harus menggunakan kepekaan dan ketajaman rohani terhadap jemaat yang dilayani 'konseli yang bermasalah' yang tidak mau terbuka tapi konselor memahami konseli perlu dilayani.

\footnotetext{
${ }^{61}$ https://hikmatpembaharuan.wordpress.com/.../pemulihan-012-keunikan-pelayanan-pe. Diakses 28
} Mei 2017

${ }^{62}$ Bahan pemulihan yang dipakai ada dalam judul buku 8 Pilihan Hidup Bahagia oleh Joh Baker.

${ }^{63}$ M.Bons Strom, Apakah Penggembalaan itu?, (Jakarta:BPK Gunung Mulia, 1999), 26

${ }^{64}$ Jay E.Adam, Andapun Boleh Membimbing, (Malang: Gandum Mas, 1986), 29 


\section{$\underline{\text { Dasar Pemulihan Alkitabiah }}$}

\section{Allah Mencari Manusia Untuk Dipulihkan}

Alkitab mencatat sejak manusia di dalam Taman Eden, Allah telah berfirman tentang rencana-Nya untuk menolong dan memulihkan umat manusia (Kejadian 3:15 direalisasikan dari Yohanes 3:16). Ini berarti memperlihatkan kemahatahuan dan kemahakuasan Allah sebagai Allah Pencipta manusia. Kepedulian Allah sebagai Allah yang berinisiatif dalam kehidupan manusia selalu berusaha untuk menyembuhkan dan memulihkan manusia sebagai ciptaan-Nya.

Alkitab mencatat ayat-ayat yang menunjukkan bahwa Allah menyembuhkan atau memulihkan keadaan jiwa manusia misalnya dalam Mazmur 147:3 "Allah menyembuhkan orang yang patah hati” Yeremia 31:25 kata orang yang lelah dan yang merana mengacu pada kondisi mental dan emosi dari tubuh batiniah, Allah pasti membuat segar dan memuaskan bagian terdalam dari keberadaan manusia. ${ }^{65}$ Jadi Allah jelas berkuasa untuk memberikan pemulihan dan menyembuhkan manusia baik secara fisik maupun batiniah. Manusia tidak bisa menyembuhkan dan memulihkan dirinya karena keterbatasan.

\section{Karya Keselamatan Dan Pemulihan Dari Tuhan Yesus}

Dalam pelayanan Tuhan Yesus untuk membawa manusia memperoleh keselamatan dan mendapatkan penyelesaian persoalan yang dihadapi, Tuhan Yesus memakai pelayanan pemulihan kepada manusia. Warren W \& David W mengatakan:

Satu hal menonjol dengan jelas: Yesus menerima orang sebagaimana adanya mereka, dan memakai pendekatan-Nya untuk memenuhi kebutuhan mereka. Dia tidak pernah memanipulasi orang-orang mengikuti "prosedur standar-Nya" karena Dia tidak punya 'standar prosedur'. Tidak ada tempat dalam pelayanan-Nya bagi 'pembicaraan wiraniaga, agama, atau mengingat-ingat percakapan itu-itu saja. Dia menemukan metafora yang sangat sesuai dengan kebutuhan orang berdosa, dan memulai dari sana. ${ }^{66}$

Dasar- dasar Alkitab tentang Tuhan Yesus memulihkan bisa dilihat dari Lukas 4:18-19, Yohanes 21 (Yesus menghadapi Petrus yang sedang patah hati). Namun inti yang terpenting yang tidak boleh diabaikan adalah bahwa Alkitab mengajarkan bahwa Yesus Kristus adalah Allah yang berinkarnasi, mati, bangkit, hidup, dan memerintah untuk menyelamatkan. Alkitab mengajarkan untuk melihat Dia sebagai Perantara - satusatunya pendamai dan pemulih hubungan antara Allah Bapa dan umat manusia. Orang yang mengalami karya keselamatan dan menerima Tuhan Yesus sebagai Tuhan dan juruselamatnya; dirinya dikatakan diciptakan untuk menjadi serupa dengan Kristus. Disinilah letak dari pertumbuhan rohani; seseorang yang ada dalam Kristus berusaha mengikuti cara dan kehendak Allah dalam menjalani kehidupannya yang mengandalkan Tuhan.

\footnotetext{
${ }^{65}$ Jay E.Adam, Andapun Boleh Membimbing..., 158

${ }^{66}$ Warren W \&David W, 10 Kekuatan..., 147
} 


\section{KESIMPULAN}

Pertama konsep diri adalah pandangan manusia tentang diri sendiri yang meliputi dimensi pengetahuan tentang diri sendiri, pengharapan mengenai diri sendiri dan penilaian tentang diri sendiri baik secara fisik, psikis, sosial, intelektual, moral maupun spiritual dalam seluruh kehidupannya. Setiap pribadi manusia bisa mengalami konsep diri irasional termasuk kaum muda baik; laki-laki maupun perempuan namun konsep diri irasional bukan merupakan faktor bawaan atau herediter. Sebab konsep diri berkembang terus sepanjang hidup manusia, namun bisa kembali normal setelah menemukan konsep diri yang tepat sesuai persfektif Allah. Konsep diri irasional muncul dalam diri seseorang karena faktor pembentukan yang mempengaruhi; bisa melalui pola asuh orang tua, lingkungan, dan pengalaman yang dinilai dalam dirinya dan menentukan itulah penilaiannya terhadap dirinya. Dampak yang diperlihatkan oleh priibadi yang mengalami konsep diri irasional tidak sesuai dengan kebenaran Alkitab dan bisa membahayakan dirinya karena itu mempengaruhi spritual - gangguan mental dalam dirinya. Oleh sebab itu setiap pribadi yang mengalami konsep diri irasional perlu ditangani dan dilayani.

Kedua, konsep diri pada manusia bahwa dirinya adalah ciptaan Tuhan ini dalam pandangan Alkitab sangat jelas. Tuhan menciptakan manusia menurut gambar dan rupaNya, manusia sangat dikasihi, dihargai dan berharga dalam pandangan Tuhan. Seperti apapun kehadiran pribadi dalam dunia, Allah mengetahui dan sudah memiliki rancangan yang indah. Karena itu seharusnya manusia memiliki penilaian terhadap konsep dirinya sesuai persfektif Allah. Tidak dapat dipungkiri akibat dosa manusia salah dan cenderung untuk melakukan kesalahan dalam menilai Tuhan dan dirinya yang berakibat manusia memiliki konsep diri irasional. Namun Allah terus mencari dan menawarkan keselamatan (Yohanes 3:16) supaya manusia tidak binasa dan dipulihkan Tuhan untuk keberadaannya. Tujuan Allah pada setiap pribadi ialah semakin bertumbuh menyerupai Kristus (Efesus 4:13-15) karena manusia dikasihi dan berharga (Yesaya 43:4).

Ketiga, dalam penelitian didapati bahwa kaum muda di GPIN Bandar Lampung ada yang mengalami konsep diri irasional. Kondisi yang diperlihatkan dan teraktualisasi sangat memprihatinkan. Karena itulah peneliti mencoba menawarkan pelayanan untuk menangani pribadi-pribadi yang mengalami konsep diri irasional dengan Model Pemulihan Alkitabiah sebagai langkah-langkah untuk memulihkan kehidupan pribadi yang mengalami konsep diri irasional.

Keempat, oleh sebab itu setelah mengadakan penelitian melalui wawancara kepada informan yang terkait baik kepada kaum muda yang mengalami konsep diri irasional, orang tua, gereja atau gembala jemaat, dan psikolog. penulis menyimpulkan bahwa, 1) Penanganan kepada kaum muda yang mengalami konsep diri irasional tidaklah mudah sebab pribadi ini tertutup dan tidak bersedia untuk siapa pun masuk dalam kehidupan pribadinya karena mengganggap dirinya benar dan bertindak benar meskipun secara sadar mengakui bahwa tidak nyaman dengan kehidupannya saat ini. 2) Tidak dapat dipungkiri keterbatasan dan kelemahan dalam penangan kepada pribadi yang mengalami konsep diri irasional sudah dilakukan oleh gereja dan orang tua. 3) Model Pemulihan Alkitabiah memang dipakai dalam melayani namun cenderung kepada konseling pribadi 
atau konseling Kristen (memecahkan masalah) bukan pemulihan (dari dosa - masa lalu - mempersiapkan untuk berani menghadapi kenyataan dan keyakinan bahwa Tuhan bersama dengan dirinya).

\section{DAFTAR PUSTAKA}

Adam, Jay E

1986 Anda-pun Boleh Membimbing, Malang: Gandum Mas.

Aqib, Zainal

2014 Ikhtisar Bimbingan Dan Konseling, Bandung: Yrama Widya.

B, Hurlock

2005 Psikologi Perkembangan Anak Jilid 2, Jakarta: Erlangga.

Baker, John

20098 Pilihan Hidup Bahagia, Jakarta: BPK Gunung Mulia.

Beek, Aart Van

2014 Pendampingan Pastoral, Jakarta: BPK Gunung Mulia.

Brill, J.Wesley

2004 Dasar Yang Teguh, Bandung: Yayasan Kalam Kudus.

Chester, \& Betsy Kylstra

$2014 \quad$ Healing Ministry, Yogyakarta: Andi.

Collins, Gary R

2010 Konseling Kristen Yang Efektif, Malang: Literatur Seminari Alkitab Asia Tenggara.

Douglas, J.D

1997

Ensiklopedi Alkitab Masa Kini 'Manusia', Jakarta: Yayasan Komunikasi Bina Kasih/OMF.

Crabb, Larry

$2008 \quad$ Konseling yang Efektif dan Alkitabiah, Yogyakarta: Andi.

Denise, Albret \& Peterfreund

1980 Great Tradition in Ethics, New York: D.Van Nostrand Company.

Dyrness, William

1979 Tema-Tema Dalam Teologi Perjanjian Lama, Malang: Gandum Mas.

E.P, Gintings

2009 Konseling Pastoral, Bandung: Jurnal Info Media.

Hadiwijono, Harun

1997 Iman Kristen, Jakarta: BPK Gunung Mulia.

Hoekema, Anthony A

2003 Manusia Ciptaan Menurut Gambar Allah, Surabaya: Momentum.

Kevin, D. Huggins

2007 Konseling Persahabatan 'Friendship Counseling', Bandung, Pionir Jaya. 
Missio Ecclesiae, 7(2), Oktober 2018, 259-286

Hulme,W.E

1996 Penggembalaan, Jakarta: BPK Gunung Mulia.

Hunt, June

2015 Pastoral Konseling Alkitabiah Jilid 2, Yogyakarta: Yayasan Andi.

Hurlock, Elizabeth B

1974 Personality Development. New York: McGraw-Hill Book Company.

Kristanto, Billy

2014 Diriku dan Kebajikan "Mengenal Diri dan Menjadi Bijak”, Surabaya:

Momentum.

Kurniawan, Nicholas

2000 Membangun Konsep Diri Berdasarkan Firman Tuhan, SAAT:

Malang.

Leigh, Ronald W

1991 Mengenal Dengan Efektif, Jakarta: BPK Gunung Mulia.

Narramore, Mark

2000 Мепији Citra Diri Kristus, Jakarta: Bina Communio.

Packer, J.L

2004 God'S Plans For You, Surabaya: Momentum

Powlison, David

2011 Konseling dan Kondisi Manusia Melalui Lensa Alkitab. Indonesia:

Momentum.

Rakhamat, Jalaluddin

1993 Psikologi Komunikasi, Bandung: Remaja Rosdakarya.

Ryrie, Charles C

2010 Teologi Dasar 1, Yogyakarta: Andi.

Setiawani, Mary dan Tong, Stephen

2010 Seni Membentuk Karakter Kristen: Hikmat Guru \& Ayah Bunda, Surabaya: Momentum.

Sidjabat, B.S

2014 Pendewasaan Manusia Dewasa, Jawa Barat: Kalam Hidup.

Sitohang, Samin. H

2005 Kasus Ksus dalam Perjanjian Lama, Bandung: Yayasan Kalam Hidup.

Soedarmo,R.

1996 Ikhtisar Dogmatika, Jakarta:BPK Gunung Mulia.

Sofyan

2013 Konseling Individual: Teori Dan Praktek, Bandung: Alfabeta.

Sproul, R.C

2005 Mendambakan Makna Diri "The Hunger For Significance, Surabaya:

Momentum 